\title{
Industrial Property and Investment in the Research in the Business Sector - Comparative Study Czech Republic and Poland
}

\section{Andrea TOMÁS̆KOV ${ }^{*}$, Roman ŚMIETAŃSKI*}

\begin{abstract}
The authors analyzed data on the topic with using descriptive statistics method for answers five research questions which are in line with the aim of the article. The aim of the paper is to perform a comparative study in the field of intellectual property and investment in research in the business sector in the Czech Republic and Poland. Data were drawn from statistical offices in the Czech Republic and Poland. In the Czech Republic. Data was processed using descriptive statistics. The number of patents and utility models has been declining in recent years, while in Poland their number is growing. On the other hand, there is a growing trend of companies investing in science and research, both in the Czech Republic and in Poland. The impulse for companies to invest in $R \& D$ is also part of long-term innovation strategies in both countries. In the Czech Republic, it is the strategy of the Czech Republic Country For The Future 2019 - 2030 and in Poland, it is the Long-term national development strategy. The article is important for making a comparison of the issue. This will be the basis for initiating academic research cooperation using tools from the long-term development strategies of both countries, which will bring implicit added value.
\end{abstract}

Keywords: patent, utility model, investment, research and development, Czech Republic, Poland.

JEL Code: O31, O32

\footnotetext{
* Ing. Andrea TOMÁŠKOVÁ, Ph.D. is assistant professor at University of Finance and Administration, Prague; Czech Republic. ORCID 0000-0003-1547-2759. Email: tomaskova.andrea@mail.vsfs.cz

${ }^{* *}$ Roman ŚMIETAŃSKI, Ph.D. is assistant professor at Opole University of Technology, Opole, Poland. Email: r.smietanski@po.edu.pl
} 


\section{Introduction}

Entrepreneurs and societies are aware that investment in the protection of the intellectual property is necessary both with regard to the elimination of future risks and in terms of increasing the value of the company's assets and thus the overall value of the company. This in turn contributes to the country's competitiveness. On the one hand, there are statistical indicators measuring financial and human resources entering to research, development and innovation, and on the other hand, there are indicators of own production of new knowledge in the form of outputs usable in practical applications, which can be protected by granting a patent or utility model. Patent data provide information on the results of research, development and innovation activities in the form of new trends in selected areas of technology and the dissemination of scientific knowledge. They also tell about the country in terms of its economic attractiveness to foreign investors.

Inventions, the creative abilities of subjects and innovations, which are reflected in practice, are important predictors of the development of companies and subsequently the development of national economies. Governments seek to implement mechanisms, forms of support and tools in their long-term strategies that should support innovation actors. In their contribution, the authors asked questions about intellectual property, companies' investments in research and their share in GDP in the Czech Republic and Poland. They analyzed data from statistical offices in the Czech Republic and Poland for the years 2015-2019. The aim of the paper is to perform a comparative study in the field of intellectual property and investment in research in the business sector in the Czech Republic and Poland. In accordance with the achievement of the goal, the authors identified five research questions (RQ1, RQ2, RQ3, RQ4, RQ5), which would lead to aim setting. The research questions are as follows:

- RQ1: What is the quantity of granted patents and utility models in the Czech Republic and Poland?

- RQ2: Which applicants are mainly granted patents and utility models?

- RQ3: What percentage of GDP does R\&D investment in the Czech Republic and Poland in 2015-2019?

- RQ4: Which workplace participates in R\&D? 
- RQ5: Which sector is mainly involved in investing in R\&D?

The ambition of the article is to initiate cooperation between the Czech and Polish academic spheres with the connection of the business environment and state authorities, which would contribute to the applicability of the invention to the practice of the economies of the countries. Make maximum using synergy effects from incentives and long-term strategies in international cooperation.

The paper is structured into four parts. The Introduction is followed by a Literature Search, Data and Methodology, Findings and Conclusion, which summarizes the findings and possible direction of future research are suggested.

\section{Literature review}

Intellectual property (IP) is understood in relation to the mind, creativity and creative activity. IPs are protected by law with goods such as patents, copyrights, trademarks. Intellectual property issues have a broad context. According to Sherman (2021), if for intellectual property blemishes it includes a formal distinction between three main categories - copyright, patents and trademarks - then the author says that intellectual property is a meaningful umbrella. The debate and rhetoric about creation, ownership, theft, fair rewards and stolen value flows across legal boundaries. According Sullivan (2020) one of the important issues for the involvement of states in the world economy, trade and international finance is intellectual property rights. Direct issues of intellectual property issues also extend to the political sphere. It is important to have a substantial, comprehensible analysis of highly technical economic, financial and political issues. By dividing the problem of intellectual property rights into its components - patents, copyrights and trademarks, the basic framework for monitoring the formulation of state policy in each of these three thematic areas (economic, financial, political) can be seen. This is followed by an inside view of policy implementation involving complex and sometimes conflicting arguments from government and commercial actors and agencies.

Legal protection allows and consents $\mathrm{s}$ to gain recognition or financial benefit from what is invented and created. IP at the commercial level and subsequently implemented in practice allows creators to differentiate themselves from the competition. In the case of a strong and stable brand, we 
speak of the protection of business identity with the possibility and potential of generating a profit and increasing the prestige of the organization (Beynon, 2018). Assets are not primarily directly linked to IP but exist independently of the medium, which has a different legal regime than the tangible asset. As an economic attribute, an intangible asset has undeniable importance (Osman, 2020). ,The protection and enforcement of intellectual property rights should contribute to the promotion of technological innovation and to the transfer and dissemination of technology, to the mutual advantage of producers and users of technological knowledge and in a manner conducive to social and economic welfare, and to a balance of rights and obligations“ (WTO, 1995).

IP considerations and inventions are key in a globalized world and ongoing process and are often a decisive factor in determining whether a product or service can be successfully established in the market (Poticha, Duncan, 2019). Whether it is possible to ensure the creator's competitiveness and stability to enter, succeed and stay in the market. IP in terms of licences and patents grant can also be seen as a tool of government policy (Manu, 2017). Intellectual property law can be linked to a degree of industrial culture and thus to industrialization, where hopes for the future are embedded in new technologies and products as a tool to achieve economic growth (Ford, 2017). The economy of industrialised countries moves away from being based on a multiplicity of independent innovators towards to one that is characterised by cross-licensing and the pooling of intellectual property rights (Beiter, 2021).

Investment in $\mathrm{R} \& \mathrm{D}$ is the driving force behind economic growth and development. Entities involved in research and development can be public institutions and universities, governments, as well as the private sector in the form of companies that can be actively motivated (Galindo-Rueda, Appelt, González-Cabral, 2018). Investment in R\&D is significantly dependent on companies' internal cash flows (Hu, Zhu, 2017). Specific investments in R\&D leads to the growth of regions and subsequently to the growth of the country's GDP (Jin et al. 2019). 


\section{Data and Methodology}

\subsection{Main items}

A patent is an authentic instrument issued by a competent patent office that provides legal protection for an invention for up to 20 years (if maintenance fees are paid) in the territory for which it has been granted by that office. A patent is applied for by filing a patent application with the relevant patent office. Patents are granted for inventions that are new, the result of inventive step and are industrially applicable (Český statistický úr̆ad, 2021).

The technical solution of the utility model, which forms its essence, which is protected after the issuance of the registration certificate, does not have to reach the creative level of the patentable invention. However, it is required to go beyond mere professional skill, not to be a mere product design, and to be industrially applicable. The utility model is not examined for eligibility for protection - ie the utility model is always registered if it meets the registration conditions set by law. A utility model cannot protect production processes. About 40 states provide utility model protection.

The inventor (the originator) is the one who created it with his own creative work. Only a natural person can be the inventor or co-inventor. This person has the right to origin (it is a personal right, not transferable to third parties). The person of the inventor is mentioned in the application for the invention and in the patent document, and the data on the inventor is entered in the patent register.

The applicant may be the inventor or his legal successor. The person of the applicant is also mentioned in the application for the invention, in the patent document and the data on the applicant are entered in the patent register. By granting a patent, the applicant becomes the owner of the patent. The patent owner has the exclusive right to use the invention, to give consent to its use to other persons (licenses) or to transfer the patent to them by a written contract. The main types of applicants are as follows: public university; public research institution; state governmental and public organizations; businesses; hospital; associations and non-profit organizations; an organizational unit of the association; natural person (Český statistický úřad, 2021; Główny Urząd Statystyczny, 2021) 


\subsection{Data}

The Czech Statistical Office in cooperation with the Industrial Property Office of the Czech Republic, as well as the Polish Statistical Office in cooperation with the Polish Patent Office, publish detailed patent statistics in various classifications, according to the OECD Patent Manual, 2009. The aim of this activity is to make information about level of patent activity of entities operating in the Czech Republic and Poland.

Data for the research were obtained from the public database of the country, they are external secondary data. Data from the Czech Republic were obtained from the database of the Czech Statistical Office, Czech Republic. Data from Poland were obtained from the database Polish Patent Office, Statistics Poland, Statistical Office in Szczecin, Eurostat. The authors were chosen a short time series of 2015-2019.

The methodological option in this case was determined on the basis of a systematic review of the literature in order to answer research questions, fulfill the goal, discuss the results and draw a conclusion. Based on the obtained data, the method of descriptive statistics was used for their processing.

\subsection{Research method}

The basic method of descriptive statistics is a method called measurements in descriptive statistics. Measurement is the process by which one statistical unit of a sample statistical set (with a range of $n$ statistical units) is assigned one of the $k$ elements of the scale $x_{1}, x_{2}, \ldots, x_{k}$. The measurement results are the finding that the element of the scale $x i(i=1,2, \ldots, k)$ was measured ni times. The sum of all values of $n_{i}(i=1,2, \ldots, k)$, which is called absolute frequency, must be equal to the range $n$ of the sample statistic.

The possible measurement results $x_{i}(i=1,2, \ldots, k)$ can be evaluated according to how likely they are to occur during the measurement. The statistical definition of probability is based on $n$ times independently performed measurements (the number of measurements $n$ corresponds to the range of the selected statistical set) and on the determined absolute frequencies ni of possible measurement results. The statistical probability $p\left(x_{i}\right)$ of the result $x_{i}$ is 
then given by the so-called relative frequency $n_{i} / n$. The sum of all relative frequencies must be equal to 1 (Záškodný et al., 2011, p. 19).

In statistical research, we are interested in mass phenomena and processes, in which we examine the regularities that manifest themselves in a large number of elements. The elements of research are statistical units. For these units, we monitor the properties of statistical units, variables. The sum of characters and quantities forms data. The measurement method and variables must meet the conditions of validity (whether what is to be measured is measured), reliability (reproducibility of the measurement) and objectivity (whether different assessors will measure statistical units in the same way). Measurement results must be arranged, graphically expressed and parameterized with suitable empirical parameters. These tasks can be accomplished using basic statistical processing. The result of elementary statistical processing is an empirical picture of the examined sample statistical set. Elementary statistical processing also completes the group of basic statistical methods that can be called descriptive statistics (Záškodný et al, 2011, p. 20, 22).

\section{Findings}

This chapter presents the results of the research based on a critical evaluation of secondary data obtained from statistical offices of the Czech Republic and Poland for the years 2015-2019.

\subsection{Patents and utility models}

From the above Figure 1 it can be seen a declining trend of granted patents of Czech applicants. The situation is completely opposite for foreign applicants. In the years 2015-2019, this is almost a 10\% annual increase. Compared to domestic, Czech entities, foreign applicants have eight to ten times more patents. In 2019, it is even fifteen times more for patents. Foreign applicants were mostly from Slovakia, Germany, then Austria and Poland. In 2019, domestic applicants were granted a total of 512 of their patents for protection by the Industrial Property Office of the Czech Republic, ie only 6 more than in the previous year. From 2015 to 2019, 3204 patents were granted 
to domestic entities and 32627 to foreign entities, with the most granted in 2019 (7571) to foreign entities and the least in 2018 (506) to domestic entities.

\section{Figure 1. Patents and Utility Models with effects in the Czech Republic by country of applicant by year of grant, 2015-2019}

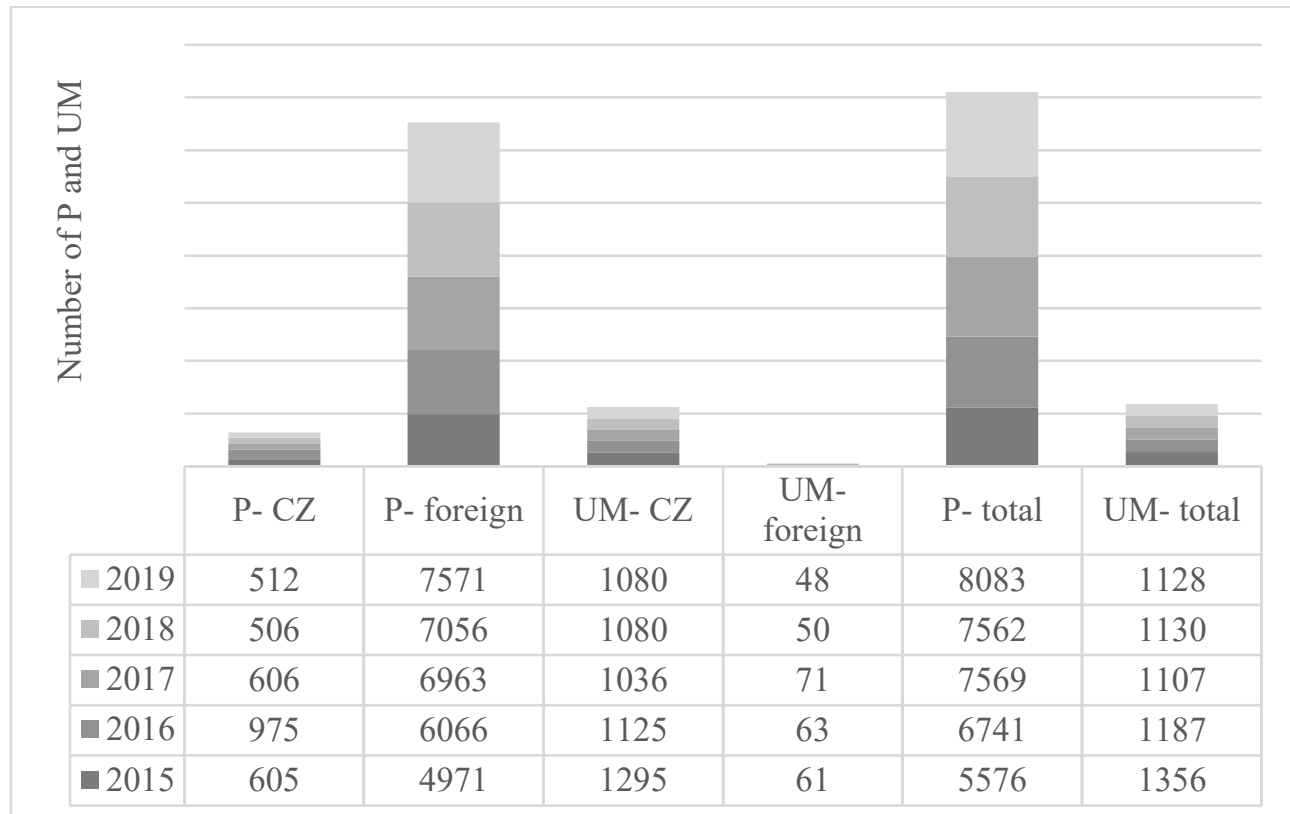

Source: Elaborated by authors based on the Czech Statistical Office, available at: https://www.czso.cz/csu/czso/patentova_statistika [visited on 05.03.2021]. Note: P - Patent, UM - Utility Model.

Since 2017, the number of patents granted to domestic entities has been declining. In 2016, the most patents were granted to domestic entities, namely 975. This is different in the case of utility models. The award of utility models is more than twenty times more for domestic applicants than for foreign applicants. In the years 2015-2019, 5616 utility models were awarded to domestic entities and 293 to foreign entities. The sum of the most granted patents was in 2019 (8083) and utility models in 2018 (1130). It is clear that there are significantly more utility models than granted patents. This fact is due to the fact that obtaining a utility model is a significantly simpler, faster and cheaper method of protection than in the case of a patent. However, in the case 
of a patent, this is a stronger form of protection. Although patents as a legal protection of technical solutions and inventions are among the traditional and at the same time most important institutes worldwide in the field of industrial property. In the Czech Republic, since the introduction of the utility model institute in 1993, an increasing share of technical solutions has been protected through this legal protection.

As in the Czech Republic, the number of registered patents in Poland is higher than in utility models. However, there are differences. In contrast to the Czech Republic, in the analyzed period 2015-2019, domestic applicants predominated in Poland. The data are shown in the following Figure 2, number of granted patents and utility models by applicant's country in 2015-2019, Poland.

According to the Figure 2, granted patents and utility models represented for more than $90 \%$ of the previous year. Regarding patents granted by the Polish Patent Office to foreign entities, for the years 2015-2019 they represented for $7 \%, 5 \%, 4 \%, 2 \%, 3 \%$ of the total number of patents. It was similar with utility models granted to foreign entities, for the years 2015 - 2019 they were $7 \%, 5 \%, 4 \%, 6 \%, 8 \%$. Here, the tendency of utility models granted to foreign entities is growing. However, when analyzing the data, it can be noted that in the following years there was a significant downward trend in the number of patents granted to foreign entities. 168 were awarded in 2015, 176 in 2016, but only 76 in 2018 and slightly more in 2019, ie 95 . In terms of the number of utility models granted, there were even fewer in absolute numbers than granted patents, although the declining trend after 2017 has been reversed. In 2019, 51 utility models were awarded and their number was the highest during the analyzed period 2015-2019.

Analysis of data for both countries on the number of patents and utility models shows large differences between the two countries. In the case of patents granted to foreign entities in the Czech Republic, their number was several times higher than in Poland, with a growing tendency.

In 2015-2019, there were almost 30, 34, 64, 95, 80 times more. On the other hand, in the case of patents granted to domestic entities, this difference in favor of Poland was largely increasing. In the years 2015-2019, there were approximately 4, 4, 5, 6, 6 times more. In the case of utility models granted in both countries to domestic and foreign entities, the differences are no longer so great. More were awarded in the Czech Republic than in Poland. In the case of 
domestic entities, this difference in 2015-2019 in the Czech Republic was approximately $130 \%, 76 \%, 33 \%, 40 \%, 79 \%$ higher than in Poland.

Figure 2. Patents and Utility Models with effects in the Poland by country of applicant by year of grant, 2015-2019

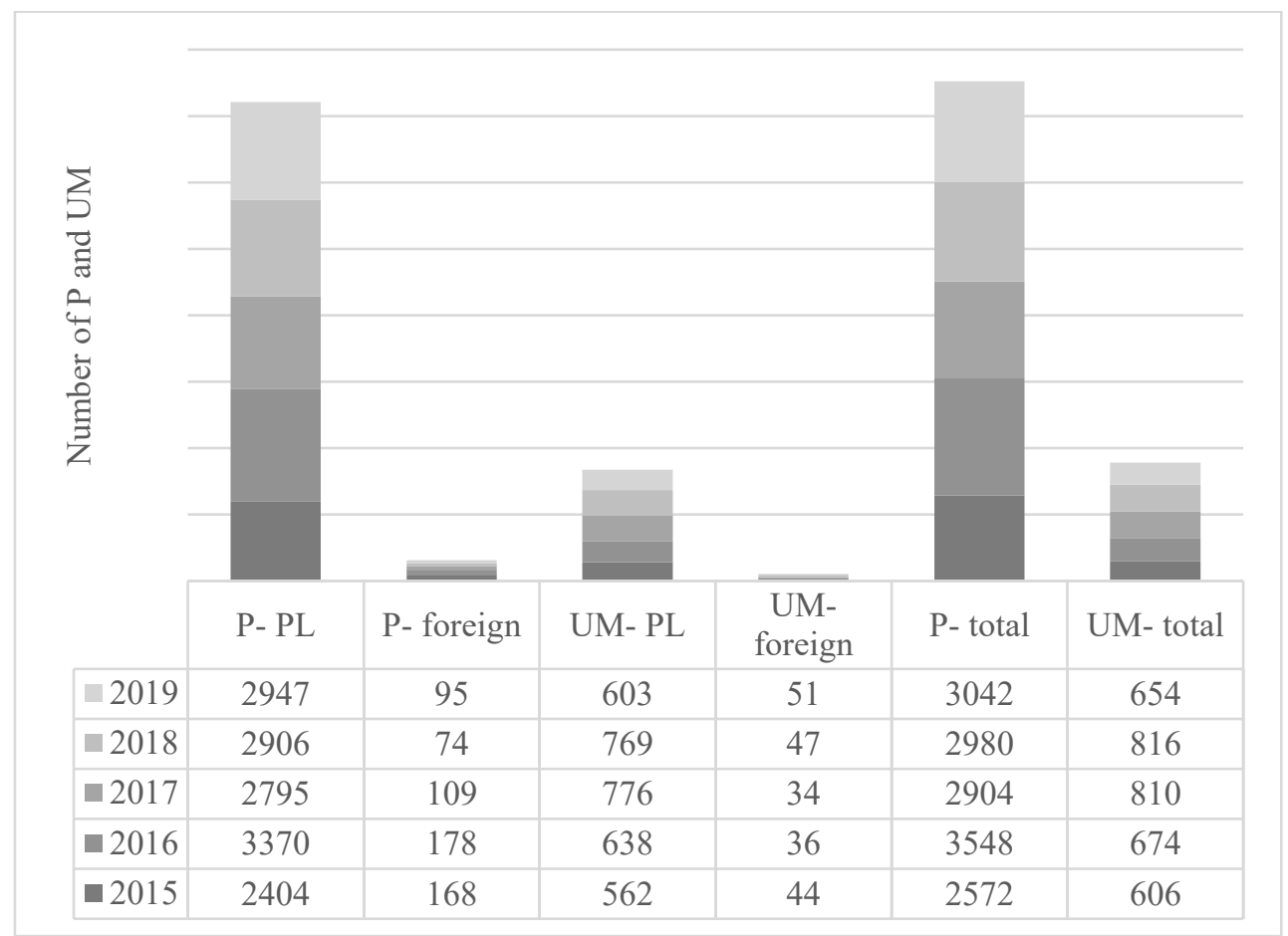

Source: Elaborated by authors based on Polish Patent Office, available at: https://uprp.gov.pl/sites/default/files/inlinefiles/Annual\%20Report\%202019.p df [visited on 07.03.2021]. Note: P - Patent, UM - Utility Model.

While in the years 2015-2018 it was also higher in the Czech Republic in the following years by approximately $53 \%, 75 \%, 109 \%, 6 \%$, but in 2019 it was already $6 \%$ lower. The trend in 2018 began to turn in favor of Poland.

Based on the above discussion, it is possible to answer RQ1: What is the quantity of granted patents and utility models in the Czech Republic and Poland? - In the analyzed years 2015-2019 in the Czech Republic and Poland, the number of granted patents predominates over utility models. Domestic applicants predominate in Poland, but foreign applicants in the Czech Republic. 
There is a time lag between the filing of the application and the grant of the patent, when the average time from the filing of the application to the grant of the patent is about 5 years. At the same time, the patent is not granted to all applicants, the success rate is around $45 \%$. Below is an overview of applicants by type of applicant, see Figure 3.

Figure 3. Patents and Utility Models registered for applicants from the Czech Republic by type of applicant, 2015-2019

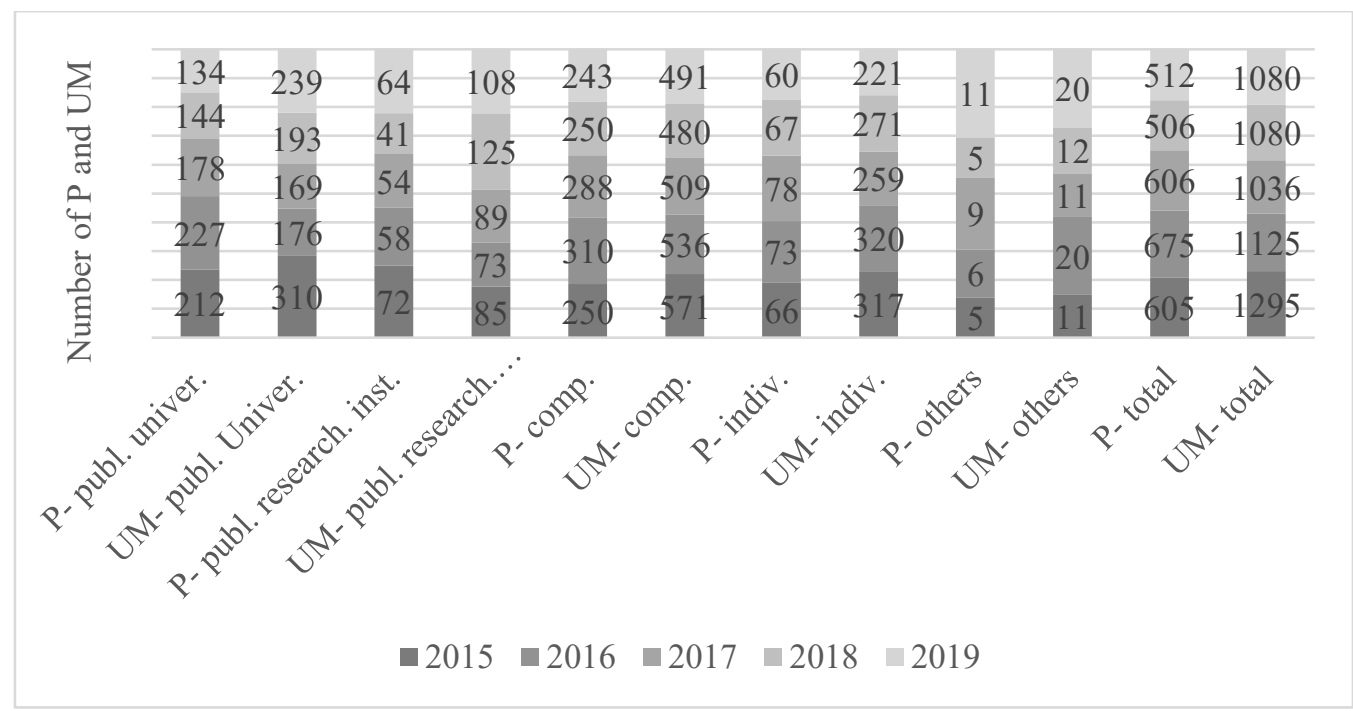

Source: Elaborated by authors based on the Czech Statistical Office, available at: https://www.czso.cz/csu/czso/patentova_statistika [visited on 02.03.2021]. Note: P - Patent, UM - Utility Model.

It has already been mentioned above that utility models predominate over patents. In the Czech Republic, according to the type of applicant, the predominant entity is enterprises, natural persons and public universities. In the case of patents, in the monitored years 2015-2019 there is a decreasing tendency for all subjects except the subject other (which includes, for example, hospitals). In the case of utility models, in the monitored years 2015-2019 there is a declining trend in public universities, companies, and individuals. On the contrary, there is an upward trend in public research institutions. A total of 2904 patents were registred between 2015-2019, the most in 2016 (675), the least in 
2019 (512) and the utility models in total 5616, the most in 2015 (1295) and the least in 2017 (1036).

In Poland, according to the type of applicant, the predominant subjects in terms of the number of registered patents, similarly to the Czech Republic, are enterprises, followed by public universities, natural persons, research centers, and the Polish Academy of Sciences scientific units. In terms of registered utility models, companies predominate. They registered more than 4 times as many utility models compared to individuals. This was followed by public universities, research centers, the Polish Academy of Sciences and scientific units. This last institution were a several-fold increase in registered utility models to 15 in 2019 (previously only 1 to 4), but this still did not improve its position. In the case of patents, in the monitored years 2015-2019 there is a variable trend for all entities, with the exception of companies, where there is a constant decrease in granted patents from 2112 in 2015 to 1665 in 2019 (27.5\%). In the case of utility models, in the monitored years 2015-2019, in contrast to the Czech Republic, a variable trend is observed in all subjects. A total of 20,956 patents were granted in 2015-2019 (18,052 more than in the Czech Republic), the most in 2015 (4,679), and in the Czech Republic in 2016. The least in 2019 (3,887), similar to in the Czech Republic, and for utility models a total of 4,829 (787 less than in the Czech Republic), the most in 2016 $(1,084)$, the most in the Czech Republic in 2015 (1295). The smallest number was in 2019 (855), in the Czech Republic it was the least in 2017 (1036). The data discussed for Poland are shown in Figure 4 below.

Based on the above discussion and the overview of Figure 3 and Figure 4 , it is now possible to answer RQ2: Which applicants were granted patents and utility models in particular? In the Czech Republic, according to the type of applicant, the predominant subjects are companies, natural persons and public universities. In Poland, according to the type of applicant, the predominant subjects, similarly to the Czech Republic, are companies, followed by public universities, natural persons and research centers.

\subsection{Research expenditures}

The Office of the Government of the Czech Republic prepares an Analysis of the State of Research, Development and Innovation in the Czech 
Republic. The analysis is divided into nine chapters describing the key topics of the R\&D system, including the focus on the innovation performance of the Czech Republic.

Figure 4. Patents and Utility Models registered for applicants from the Poland by type of applicant, 2015-2019

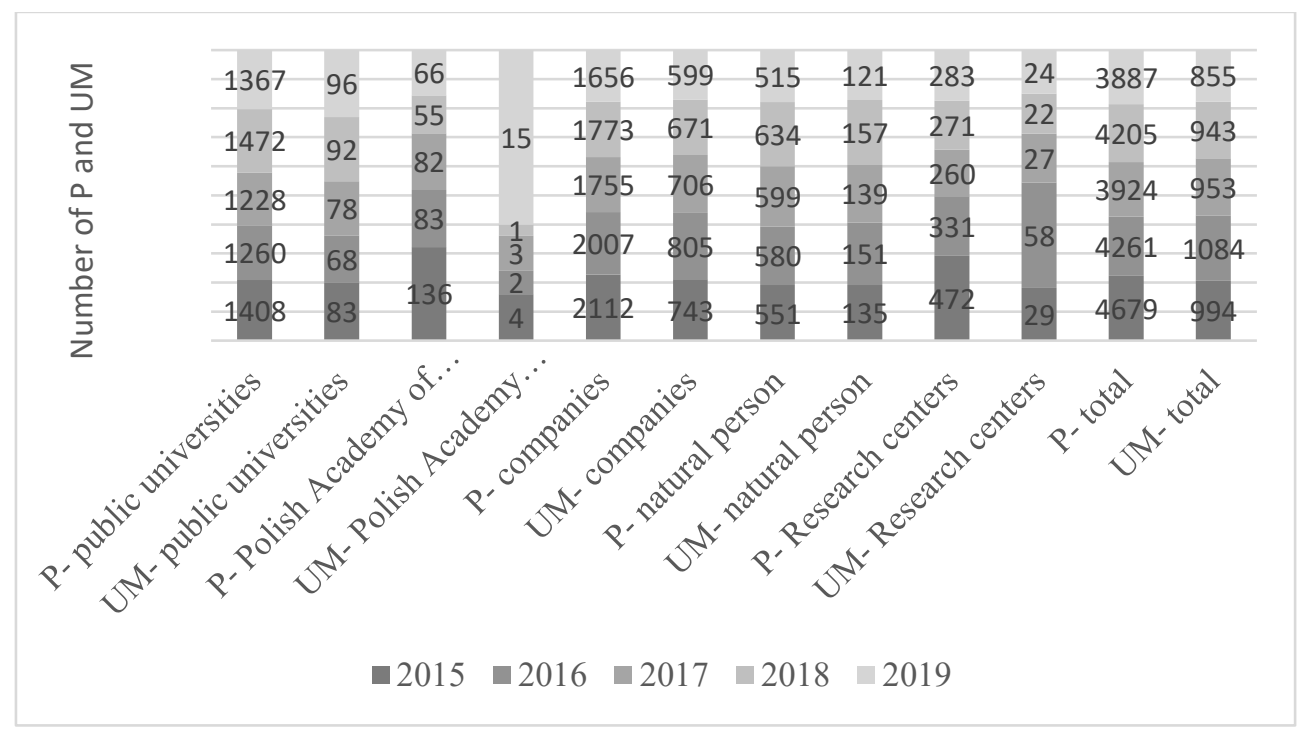

Source: Elaborated by authors based on Polish Patent Office, available at: https://uprp.gov.pl/sites/default/files/inlinefiles/Annual\%20Report\%202019.p df [visited on 07.03.2021]. Note: P - Patent, UM - Utility Model.

The main chapters of the analysis are devoted to financial flows in $R \& D$, financing of research and development from the state budget, support of research, development and innovation in the Czech Republic from European funds, implementation of the National Research and Innovation Strategy for smart specialization of the Czech Republic, human resources in research and development, research infrastructures, research and development results, innovation performance of the Czech economy and its international comparison, and international cooperation in R\&D and innovation.

There has been a long-term increase in expenditure on R\&D in the Czech Republic. In 2019, for the second year in a row, expenditures exceeded CZK 100 billion. It spent CZK 102.8 billion on R\&D in 2018 and CZK 111.6 billion 
in 2019. In relation to GDP, R\&D expenditure in 2018 increased from $1.9 \%$ to $1.94 \%$ in 2019, see Figure 5 below. The Czech Republic thus approached the EU average. Within the EU countries, it ranks tenth behind the Netherlands and Slovenia, but surprisingly, for example, ahead of the United Kingdom. Ten years ago, the Czech Republic was sixteenth in this statistic. However, the Czech Republic is still losing out to the most developed European countries. The European goal - to spend more than $3 \%$ of GDP on R\&D - is currently met only by Sweden, Austria, Germany and Denmark (Věda a výzkum.cz, 2020). Below Figure 5 Expenditures on R\&D and share in GDP in 2015-2019 in the Czech Republic.

\section{Figure 5. Expenditures on R\&D and share in GDP, Czech Republic, 2015-2019}

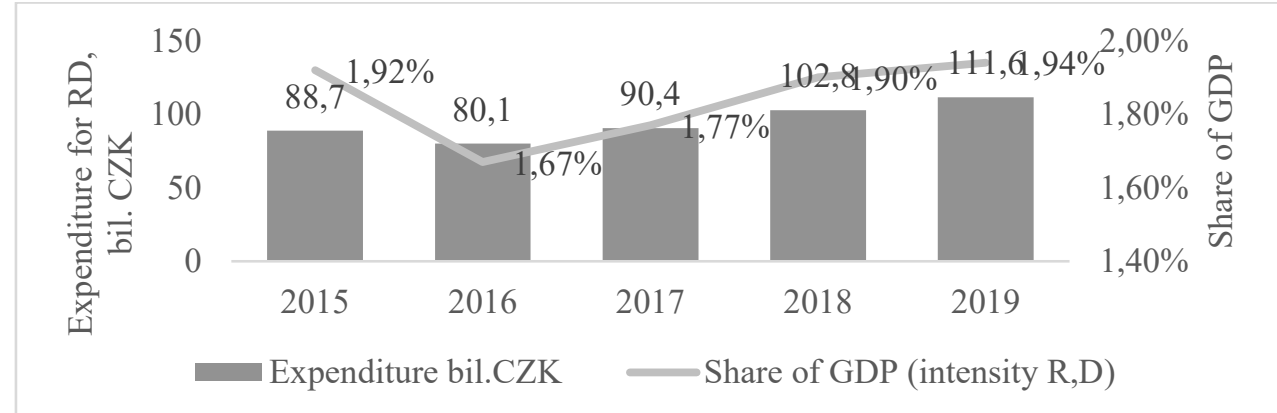

Source: Elaborated by authors based on Věda a výzkum.cz, available at: https://vedavyzkum.cz/politika-vyzkumu-a-vyvoje/politika-vyzkumu-avyvoje/vydaje-na-vyzkum-a-vyvoj-podruhe-v-rade-prekonaly-stomiliardovou-hranici [visited on 02.03.2021]

In Poland, as well as in the Czech Republic, an analysis of the situation of research, development and innovation is being prepared. This analysis is prepared by the Central Statistical Office. The analysis includes state budget expenditures on $\mathrm{R} \& \mathrm{D}$, their impact on employment and includes four sectors: the government sector, the corporate sector, the higher education sector, the private non-commercial institutions sector. A comparative analysis of data on R\&D expenditures and their share in GDP in 2015-2019 in Poland and the Czech Republic shows that these expenditures are increasing in both countries. Expenditure on R\&D and their share in GDP in Poland in 2015-2019 is shown 
in the following Figure 6 below. In 2015-2019, R\&D expenditure for the following years was: $1 \% ; 0.96 \% ; 1.03 \% ; 1.21 \% ; 1.32 \%$ of GDP expenditure. In 2016, expenditure on R\&D was slightly lower than in 2015 (less than 1 percent), but since 2016 it has been constantly increasing. In 2019, they were almost $69 \%$ higher than in 2016. In the same period, the increase in expenditure in the Czech Republic was more than $39 \%$, ie it was lower than in Poland.

\section{Figure 6. Expenditure on R\&D and the share of GDP, Poland, 2015-2019}

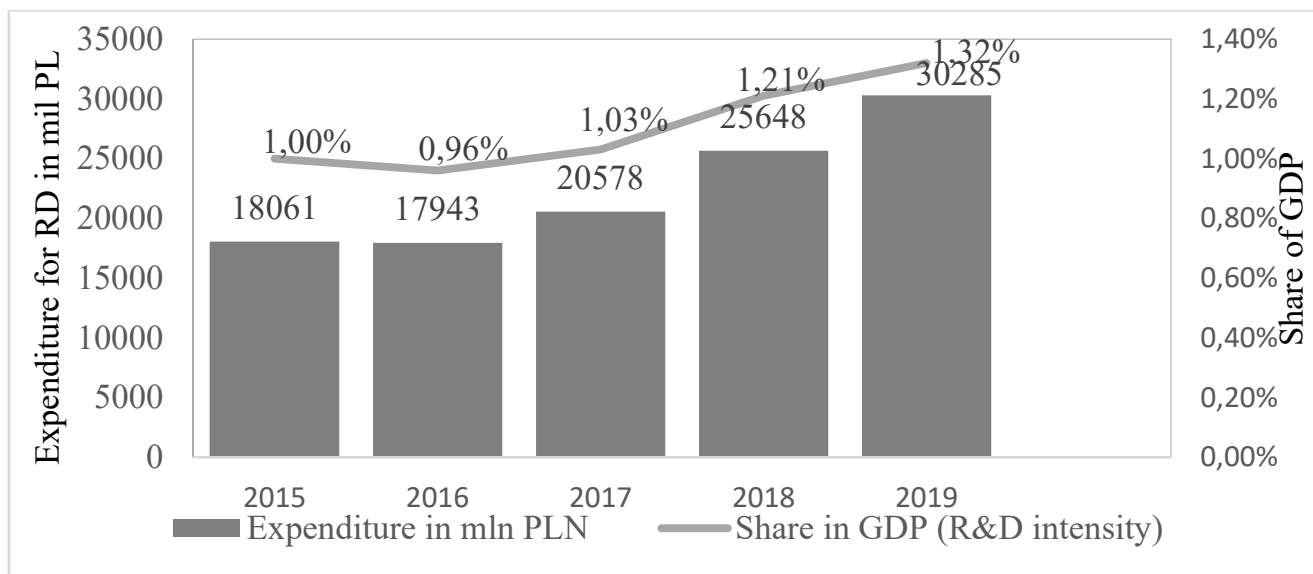

Source: Elaborated by authors based on Główny Urząd Statystyczny, available at: https://stat.gov.pl/obszary-tematyczne/nauka-i-technika-spoleczenstwoinformacyjne/nauka-i-technika/dzialalnosc-badawcza-i-rozwojowa-w-polscew-2019-roku, 15,4.html [visited on 02.03.2021]

In the Czech Republic, however, it represents a larger share of expenditure in GDP. In 2015-2019 it was higher by $0.92 \% ; 0.71 \% ; 0.74 \%$; $0.59 \% ; 0.62 \%$.

Based on the above discussion and Figure 5 and Figure 6, it is possible to answer RQ3: What percentage of GDP is invested in R\&D in the Czech Republic and Poland in 2015-2019? - In relation to GDP, R\&D expenditure increased in 2018 from $1.9 \%$ to $1.94 \%$ in 2019. In 2015, the share was 1.92 $\%$, followed by a decrease to $1.67 \%$ in 2016 and from 2017 the percentage share of R\&D investment in GDP is already growing. In Poland, as in the Czech Republic, there is an upward trend in investment in R\&D. The share of these investments in relation to GDP was still $1.03 \%$ in 2017, but in 2019 it reached 
$1.32 \%$. The Czech Republic is growing faster than in Poland, with an upward trend in both countries.

For many years, it has been the case that business resources have the largest share in the financing of R\&D in the Czech Republic. Last year it was $58 \%$. In 2019, companies invested almost CZK 65 billion in R\&D activities from their sources, mainly in their own in-house R\&D. According to statistics from the Czech Statistical Office, CZK 37.5 billion was spent from public domestic sources in 2019, which is CZK 2.5 billion more than in 2018. The state budget accounted for about one third of $R \& D$ and public foreign resources accounted for about $7 \%$ of total R\&D expenditure. Finance from the state budget has been growing significantly since 2016, and in terms of the share of public expenditure on R\&D in GDP, the Czech Republic is above the EU average (ČSÚ, 2021).

Regarding R\&D workplaces in R\&D workers in sectors, academic entities predominate, followed by entreprise sector and governmental sector. In the monitored years 2015-2019, an upward trend in the number of R\&D workplaces in all sectors can be seen. It can be concluded that the upward investment rate will be reflected in an increasing trend in the number of utility models and patents over a number of years, see Figure 7.

Figure 7. R\&D workers in sectors, Czech Republic, 2015-2019

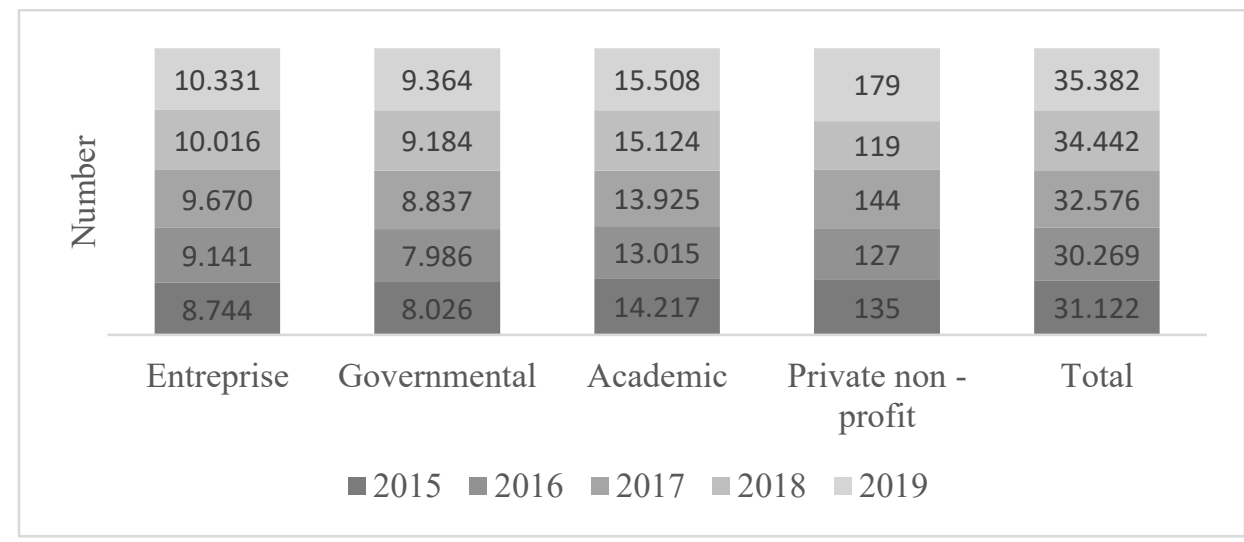

Source: Elaborated by authors based on the Czech Statistical Office, available at: https://www.czso.cz/csu/czso/statistika_vyzkumu_a_vyvoje [visited on 02.03.2021] 
As in the Czech Republic, R\&D expenditures contribute to employment growth in this area. In the analyzed years 2015-2019, according to the data of the Central Statistical Office mentioned in Figure 8 below, an upward trend in the total number of jobs in R\&D can be observed.

Figure 8: R\&D workers in sectors, Poland, 2015-2019

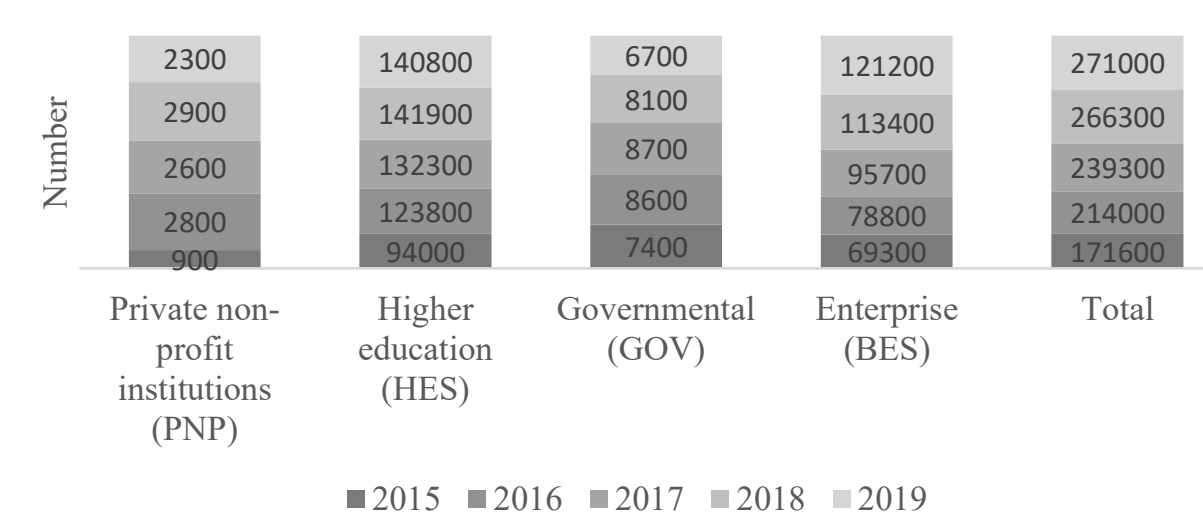

Source: Elaborated by authors based on Główny Urząd Statystyczny, available at: https://stat.gov.pl/obszary-tematyczne/nauka-i-technika-spoleczenstwoinformacyjne/nauka-i-technika/dzialalnosc-badawcza-i-rozwojowa-w-polscew-2019-roku, 15,4.html [visited on 02.03.2021]

Looking at the Figure 8 data, it can be seen that the pace of R\&D investment by workplace is increasing. It is clear that the increasing pace of $R \& D$ expenditure in recent years has resulted in an increase in the employment of R\&D personnel in the Higher education (HES) and Enterprise (BES) sectors. However, this pace was not proportional to the increase in internal R\&D funding. This could be a sign of better use of R\&D actors. Overall, from 2016 to 2019 , the growth rate of employees employed in R\&D increased by $27 \%$. The situation by sector is as follows: an increase of $54 \%$ in the business sector (BES), an increase of $14 \%$ in the higher education sector (HES), while a decrease of $18 \%$ in the private non-profit institution (PNP) sector and $22 \%$ in the general government sector. In the latter sector, there was also a $15 \%$ decrease in internal R\&D funding in the analyzed period 2015-2019.

Based on Figure 7 and Figure 8 can be answered RQ4: Which workplace participates in R\&D? In Poland, as well as in the Czech Republic, in the analyzed years 2015-2019, the number of workplaces in R\&D in higher 
education (HES) and the business (BES) sectors are growing. In both sectors, $\mathrm{R} \& \mathrm{D}$ funding is increasing at a faster rate compared to the number of workers involved in R\&D. This should be assessed positively, as it may indicate, among other things, better use of employees (their knowledge and skills) or a proper assessment of their qualifications. This is also confirmed by the growing number of patents and utility models granted to Polish entities. It should be borne in mind that, given the growing $R \& D$ expenditure in recent years, the implications and effects of creating many patents and utility models will be visible in the coming years. Obviously, their creation requires a long time horizon. One of the factors influencing economic development is R\&D expenditure, without this one no economy will be innovative.

Simultaneously with the number of R\&D workplaces in companies, investments of companies in research have been increasing in recent years, below Figure 9. In the Czech Republic, the business sector participates in R\&D expenditures. Expenditures have increased mainly since 2017. The academic sector follows, where expenditures on R\&D have increased significantly since 2018. In the general government sector, R\&D investment declined over the next three years in 2015. The growth did not occur until 2019, when it leveled off in 2019. Investments in $R \& D$ in the private non-profit sector are quite minimal.

\section{Figure 9. R\&D expenditure in sectors, Czech Republic, 2015-2019}

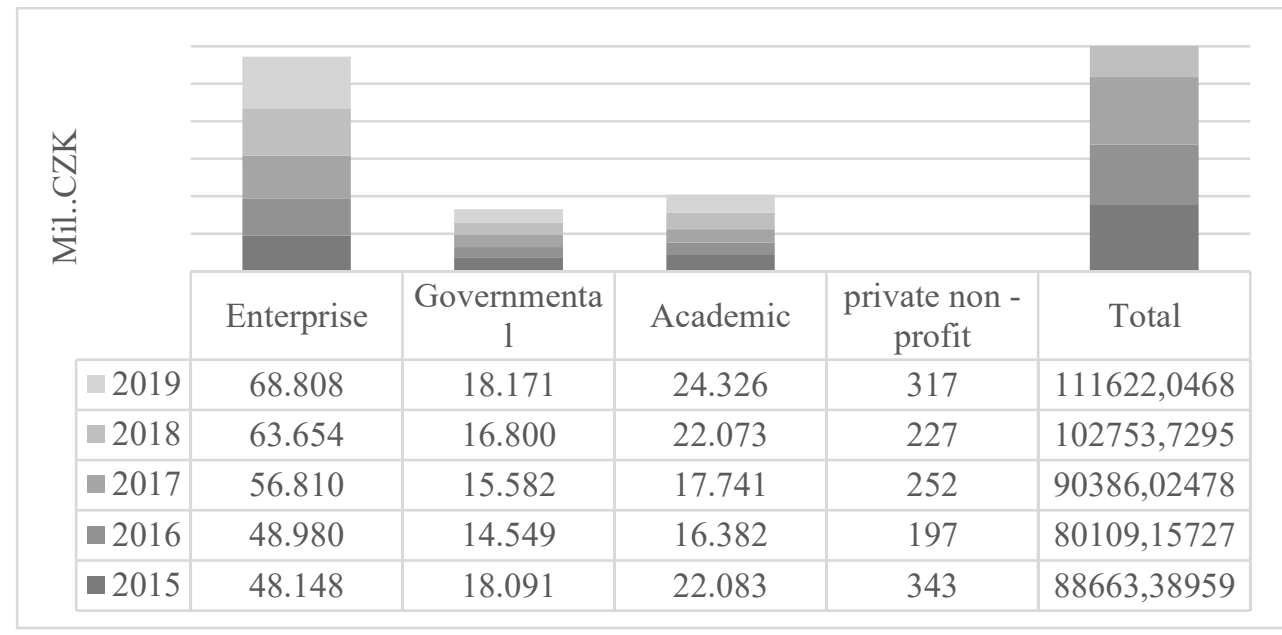

Source: Elaborated by authors based on the Czech Statistical Office, available at: https://www.czso.cz/csu/czso/statistika_vyzkumu_a_vyvoje [visited on 05.03.2021] 
In Poland, as in the Czech Republic, resources from the business sector have had the largest share in R\&D funding in recent years, see Figure 10. In 2015 , they were for almost $47 \%$, but in the following years more than $60 \%$ per year. In 2019, they were for almost $63 \%$ and were 5\% higher than in the Czech business sector. The share of higher education in R\&D funding has exceeded $30 \%$ in the last four years. On the other hand, the general government sector has not exceeded $3 \%$ over the last four years (with the exception of 2015 , when expenditure was $24.4 \%$ ) and the private non-commercial institutions (PNPERD) sector has not exceeded $1 \%$ since 2015, education accounts for more than $90 \%$ of internal R\&D funding. The growth rate of funds allocated to internal R\&D financing over the last four years was recorded in three sectors: by $91 \%$ in the higher education sector (HERD), by $62 \%$ in the business sector (BERD), by $14 \%$ in the private non-commercial institutions sector (PNPERD), while a decrease of $15 \%$ was recorded in the general government sector (GOVERD). Overall, for the period 2015-2019, the increase in internal R\&D funding was $69 \%$, see Figure 10 below.

\section{Figure 10. R\&D expenditure in sectors, Poland, 2015-2019}

\begin{tabular}{|r|c|c|c|c|}
\hline & & & & \\
\hline
\end{tabular}

Source: Elaborated by authors based on Główny Urząd Statystyczny, available at: https://stat.gov.pl/obszary-tematyczne/nauka-i-technika-spoleczenstwoinformacyjne/nauka-i-technika/dzialalnosc-badawcza-i-rozwojowa-w-polscew-2019-roku, 15,4.html [visited on 02.03.2021] 
Based on the previous discussion and Figure 9 and Figure 10, it is possible to answer RQ5: Which sector is mainly involved in investing in R\&D? Regarding investments in R\&D sector in the Czech Republic, businesses entities predominate, followed by academic and governmental entities. In the case of Poland, as in the Czech Republic, the business sector predominates and the higher education sector also has a high share.

A stable business environment of the country and its clear long-term strategy is essential for companies' investments in research. The Innovation Strategy of the Czech Republic 2019 - 2030 Czech Republic Country For The Future is set in the Czech Republic, which has 9 main pillars. The first pillar is the Financing and evaluation of research and development. The aim of the Strategy is, among other things, to prepare a fundamental amendment to the Act on the Support of Research, Experimental Development and Innovation, which would better reflect the level that the Czech Republic wants to achieve, and significantly strengthen funding for research, development and innovation from $1.79 \%$ of GDP in 2019 to $3 \%$ of GDP in 2030 (Country for the future, 2021).

It is important to realize that innovation is one of the conditions influencing the improvement of the international position of Polish companies, which means that they can participate more effectively in the market economy. Therefore, it is necessary to increase spending on $R \& D$, which means the involvement of the state and businesses. Face to international competition in R\&D is one of the key challenges for Polish development policy in the next two decades. In 2013, the Polish government developed a strategy that envisages a gradual increase in the level of expenditure on science, R\&D (DSRK PL2030, 2013). Although R\&D expenditures in Poland and the Czech Republic are growing every year, they still have a low volume of investments and a percentage share of these expenditures in relation to GDP compared to the EU average. According to the analysis of Eurostat data in Poland and the Czech Republic, expenditure on internal R\&D (GERD) increases in both countries in 2015-2019, Fig. 11.

As mentioned above, in terms of R\&D expenditure as a share of GDP, the Czech Republic invested $1.94 \%$ in R\&D in 2019 in terms of its share of GDP, while Poland invested $1.32 \%$ of GDP in R\&D. According to Eurostat data (2021), the share of $1.94 \%$ of GDP ranks the Czech Republic 10th in the EU and Poland 18th. The amount of R\&D allocations has increased in most European countries. 
Figure 11. Intramural R\&D expenditure, selected countries, 2015 - 2019

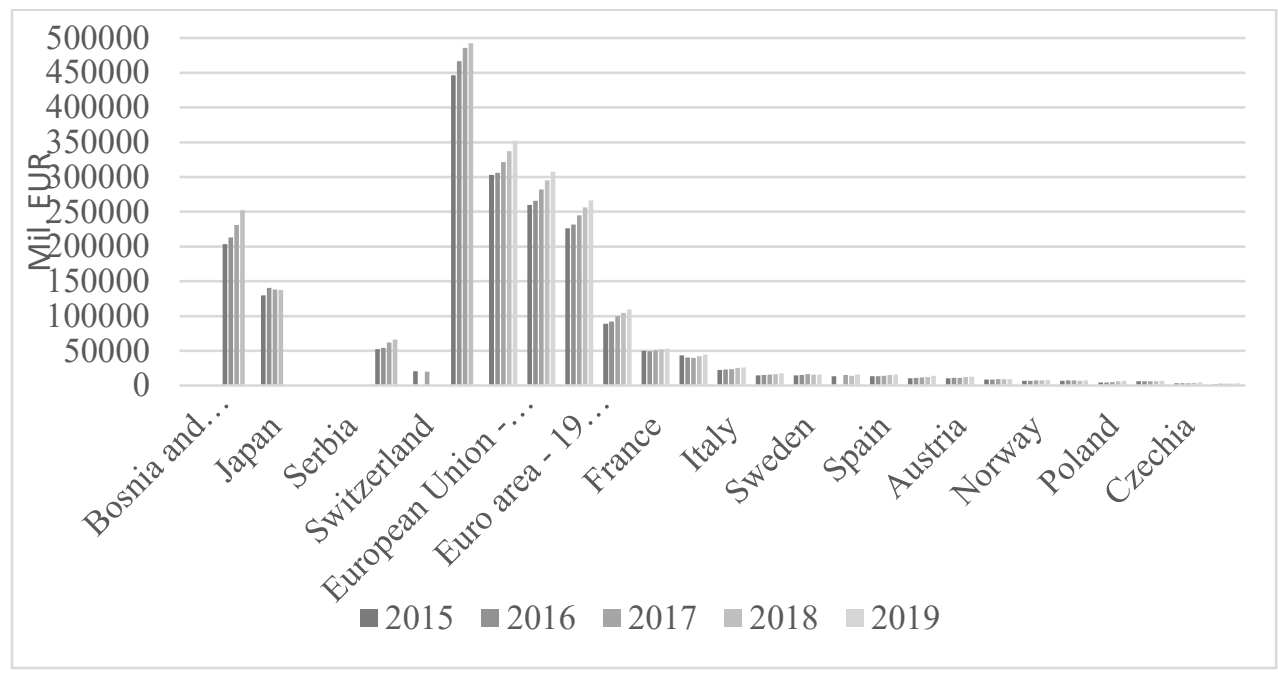

Source: Elaborated by authors based on Eurostat; Intramural R\&D expenditure (GERD) by sectors of performance and type of costs - Products Datasets Eurostat, available at: https:/ec.europa.eu/eurostat/web/products-datasets//rd_e_gerdcost [visited on 07.03.2021].

The Association of Small and Medium-Sized Enterprises and SelfEmployed Persons in the Czech Republic conducted a survey in 2020 on a sample of 300 SMEs, which concerned innovations in domestic companies. The results of the survey are as follows. Most companies plan to innovate in the next 12 months. On the contrary, $6 \%$ of respondents do not plan to invest. This is a classic development, companies know that they cannot afford stagnation, but unfortunately in recent years investment in innovation has been hampered by high wages and a lack of a capable workforce. In what areas will innovation be directed? Innovation will most often be aimed at strengthening overall competitiveness (52\%), expanding products and services (46\%), regular investment in business development and product and service development (30\%), automation and digitization (29\%) and addressing shortcomings. workforce (27\%). The issue of labor shortages is long-term. The Czech Republic has a low unemployment rate. How will the innovations be financed? Enterprises use mainly their own resources (79\%), bank loans (35 $\%$ ), subsidies (27\%), intercompany loans (7\%) and foreign capital or the entry 
of a Czech investor (3\%) (Asociace malých a středních podniků a živnostníků, 2020).

\section{Conclusion}

Utility and industrial design, patent, trademark or copyright are increasingly inflected terms not only of large companies, but are increasingly becoming a natural vocabulary of small and medium-sized companies. The approach of companies to new knowledge is one of the key factors in the innovation process. The approach to knowledge through technological cooperation with other companies is also important, as well as interaction with knowledge providers such as research institutions and universities.

These entities are important applicants for patents and utility models in the Czech Republic and Poland. In the Czech Republic and Poland, the number of granted patents prevails over the number of utility models. Domestic applicants predominate in Poland and foreign applicants in the Czech Republic. In the Czech Republic, according to the type of applicant, the predominant subjects are companies, natural persons and public universities. In Poland, according to the type of applicant, the predominant subjects, similarly to the Czech Republic, are companies, followed by public universities, natural persons and research centers. In the Czech Republic and Poland, the number of R\&D workplaces in the business sector is increasing. Nevertheless, the industry lacks innovation, the development of new technologies and a focus on research. This in turn hinders the development of industry for value-added production.

In the Czech Republic, in relation to GDP, R\&D expenditure increased in 2018 from $1.9 \%$ to $1.94 \%$ in 2019. In Poland, as in the Czech Republic, there is an upward trend in investment in R\&D. The share of these investments in relation to GDP was $1.03 \%$ in 2017 , but in 2019 it reached $1.32 \%$.

Investment in research and development in relation to competitive activity and new opportunities are pragmatic reasons why entrepreneurs today consider the management of the intellectual property as one of their priorities and implement it in their strategic plans. Regarding investments in R\&D in the sector in the Czech Republic, businesses entities predominate, followed by akademic sector and governmental sector. In the case of Poland, as in the Czech Republic, the business sector predominates and the higher education sector also has a high share. Most companies expect an increase in investment in research and development in 2021. Possible reasons why companies plan to invest in 
research in the future may be as follows. The limited availability of qualified staff is one of the most significant obstacles to the development of research and innovation activities of Czech companies. In addition, investments in the development of public sector research capacities made in recent years may lead to an outflow of some highly skilled workers who might otherwise be involved in technological research in private companies. The potential for growth of private investment in public research lies in fields with a strong research base, innovative capacities of companies and existing links. It is important to realize that investment in $\mathrm{R} \& \mathrm{D}$ is a prerequisite for improving the international position of companies.

Therefore, it is necessary to increase expenditure on research and development. Although expenditure on R\&D in Poland and the Czech Republic is growing every year, they still have a low volume of investment and a percentage of this expenditure in relation to GDP compared to the EU average. In 2013, the Polish government developed a strategy for Poland 2030, The Third Wave of Modernity. Long - term national development strategy, which assumes a gradual increase in the level of expenditure on science, research. The long-term strategy of the Czech Republic Country For The Future 2019 - 2030 has the help of the growth of investments in the field of science and research in the case of the Czech Republic. States implement incentive mechanisms, forms of support and instruments into their long-term strategies.

The results and cooperation of authors from two countries have the ambition to initiate cooperation between the Czech and Polish academic spheres with the interconnection of the business environment and state authorities, which would contribute to the applicability of the invention to the practice of national economies. Make maximum use of synergy effects from long-term strategies of countries within the framework of international cooperation.

Future research recommendations: The authors set this research as an initial stage. In the future, it is planned to draw on the tools of the long-term Strategies of both countries. In particular, draw on programs to support research for the business environment, based on open submissions.

Research limitations: The limitations of research can be found in the issues of different countries. Limits may be due to differences in information and the actual collection of samples and data in national databases, their interpretation and objectivity for comparision. 
Acknowledgement: The result was created in solving the student project Intergenerational transfer of family crafts - a challenge for the 4.0 phenomenon, No. $7427 / 2020 / 03$ using objective oriented support for specific university research of the University of Finance and Administration.

\section{References}

Asociace malých a středních podniků a živnostníků (2021). Investice v malých a středních firmách. [visited on 02.03.2021]. Retrieved from https://amsp.cz/wp-content/uploads/2020/10/IPSOS-proAMSP_Inovace-v-MSP_09_2020-WEB.pdf

Beiter, K. D. (2021). Reductionist intellectual property protection and expansionist (and "Prodevelopment") competition rules as a human rights imperative? enhancing technology transfer to the global south. Law and Development Review, Vol. 14, No. 1, 215-272. doi:http://dx.doi.org/10.1515/1dr-2020-0079

Benyon, W. (2018). Intellectual property is a bread and butter issue for businesses: Wayne Beynon, intellectual property lawyer, explains the importance of protecting intellectual property in business. Retrieved from https://search.proquest.com/newspapers/intellectual-property-isbread-butter-issue/docview/2091531708/se-2?accountid $=37662$

Country for the future (2021). Country for the future. [visited on 05.03.2021]. Retrieved from https://www.countryforfuture.com/pilir/rd/\#more-info

Český statistický úřad (2021). Patentová statistika. Retrieved from: https://www.czso.cz/csu/czso/statistika_vyzkumu_a_vyvoje

Český statistický úrad (2021). Patentová statistikă. Retrived from: https://www.czso.cz/csu/czso/patentova_statistika

Eurostat (2021). Intramural R\&D expenditure (GERD) by sectors of performance and type of costs - Products Datasets - Eurostat. Retrieved from: https://ec.europa.eu/eurostat/web/productsdatasets/-/rd_e_gerdcost

Ford, L. R. (2017). Intellectual property and industrialization: Legalizing hope in economic growth. Theory and Society, Vol. 46, No. 1, pp. 57-93.

Galindo-Rueda, F., Appelt, S., and González-Cabral, A. (2018). Indicators of R\&D tax support. Issues in Science and Technology, No. 34, pp. 85-88. Retrieved from: https://search.proquest.com/scholarlyjournals/indicators-r-amp-d-tax-support/docview/2177530556/se2? accountid $=37662$ 
Główny Urząd Statystyczny (2021). Research and experimental development in Poland in 2015 - 2019. Retrieved from: https://stat.gov.pl/obszarytematyczne/nauka-i-technika-spoleczenstwo-informacyjne/nauka-itechnika/dzialalnosc-badawcza-i-rozwojowa-w-polsce-w-2019roku, 15,4.html

Hu, J., Li, G., and Zhu, F. (2017). Regional financial developments and research and development investment-cash flow sensitivity: Evidence on chinese public high-tech companies. International Review of Finance, Vol. 17, No. 4, pp. 627-643.

Jin, J., Zhao, R., Yang, Y., and Min, C. (2019). Endogenous study on economic development, environmental investment, and green development based on the panel data analysis of 11 provinces in the yangtze river economic belt. Journal of Coastal Research, Vol. 98, No. 2 pp. 426-432.

Louise, v. G., \& Gobac, I. (2021). Building respect for intellectual propertyThe journey toward balanced intellectual property enforcement. The Journal of World Intellectual Property, 24(1-2), 167-185. doi:http://dx.doi.org/10.1111/jwip.12177

Manu, T. (2017). The complexity of using the patent standards under TRIPS for the promotion of domestic industrial development in developing countries in the absence of local working requirements: Rethinking the role of the world intellectual property organization in intellectual property standard-setting. Journal of World Trade, No. 51, pp. 517-528. Retrieved from: https://search.proquest.com/scholarlyjournals/complexity-using-patent-standards-undertrips/docview/1968047358/se-2?accountid=37662

Ministerstwo Administracji i Cyfryzacji (2021). Trzecia fala nowoczesności. Dlugookresowa Strategia Rozwoju Kraju. Retrieved from: http://kigeit.org.pl/FTP/PRCIP/Literatura/002_Strategia_DSRK_PL203 0 RM.pdf

Osman, B. B. (2020). From intangible assets to intellectual property: delineating the intellectual property commercialization from the legal perspective. Lex Et Scientia, No. 27, pp. 86-95. Retrieved from: https://search.proquest.com/scholarly-journals/intangible-assetsintellectual-property/docview/2473443012/se-2?accountid=37662

Polish Patent Office (2019). Annual Report. Retrieved from: https://uprp.gov.pl/sites/default/files/inlinefiles/Annual\%20Report\%202019.pdf 
Poticha, D., and Duncan, M. W. (2019). Intellectual property-The foundation of innovation: A scientist's guide to intellectual property. Journal of Mass Spectrometry, Vol. 54, No. 3, pp. 288-300.

Sherman, Z. (2021). The color of creatorship: Intellectual property, race, and the making of americans. Rethinking Marxism, 33(2), 324-326. doi:http://dx.doi.org/10.1080/08935696.2021.1893089

Sullivan, L. R. (2020). Zhengqing zhang, 0RW1S34RfeSDcfkexd09rT2intellectual property rights in china1RW1S34RfeSDcfkexd09rT2 (philadelphia: University of pennsylvania press, 2019) 298 P. \$54.58 hardback. Journal of Chinese Political Science, 25(3), 525-526. doi:http://dx.doi.org/10.1007/s11366020-09664-w

Věda a výzkum.cz. (2020). Výdaje na výzkum a vývoj podruhé v radě překonaly stomiliardovou hranici. Retrieved from: https://vedavyzkum.cz/politikavyzkumu-a-vyvoje/politika-vyzkumu-a-vyvoje/vydaje-na-vyzkum-avyvoj-podruhe-v-rade-prekonaly-stomiliardovou-hranici

World Trade Organization. 1995. Agreement on Trade-related Aspects of Intellectual Property Rights, Article 7. Retrieved from: https://www.wto.org/english/docs_e/legal_e/27-trips_03_e.htm

Záškodný, P. Havránková, R. Havránek, J. and Wurm, V. (2011). Základy statistiky. Praha: Curriculum. 